\title{
A unique vaccine for birth control and treatment of advanced stage cancers secreting ectopically human chorionic gonadotropin
}

\author{
Gursaran P. Talwar ${ }^{*}$, Jagdish C. Gupta ${ }^{1}$, Shilpi Purswani ${ }^{1,2}$, Hemant K. Vyas ${ }^{1,3}$, Kripa N. Nand ${ }^{1}$,
} Priyanka Pal ${ }^{1}$, Krishna M. Ella ${ }^{4}$

\author{
${ }^{1}$ Talwar Research Foundation, New Delhi 110068, India \\ ${ }^{2}$ Qiagen Sciences Inc., Germantown, MD 20874, USA \\ ${ }^{3}$ uniQure USA, Lexington, MA 02421, USA \\ ${ }^{4}$ Bharat Biotech International Ltd, Hyderabad, Telangana 500078, India
}

*Correspondence: Gursaran P. Talwar, Director Research, Talwar Research Foundation, E-8, Neb Valley, New Delhi 110068, India.gptalwar@gmail.com

Academic Editor: Dominique J. Charron, Hospital Saint Louis, France

Received: June 19, 2021 Accepted: September 29, 2021 Published: December 31, 2021

Cite this article: Talwar GP, Gupta JC, Puruswani S, Vyas HK, Nand KN, Pal P, et al. A unique vaccine for birth control and treatment of advanced stage cancers secreting ectopically human chorionic gonadotropin. Explor Immunol. 2021;1:[Online First]. https://doi.org/10.37349/ei.2021.00026

\begin{abstract}
This article is a tribute and homage to Gerard Chaouat who invited me to contribute this article. My years in France have remained very memorable to me. Reviewed briefly is the vaccine that was made against human chorionic gonadotropin (hCG) to prevent unwanted pregnancy in sexually active women. It has now been developed as a genetically engineered recombinant vaccine and passed onto industry for its production under good manufacturing practices (GMP) conditions for confirmatory trials. The trials have received the approval of the Drugs Controller General of India. The trials have started but have been interrupted by the coronavirus disease 2019 (COVID-19) pandemic. This vaccine is likely to have another highly beneficial application in the treatment of cancers expressing ectopically hCG.
\end{abstract}

\section{Keywords}

Prevention of pregnancy, recombinant vaccine, Mycobacterium indicus pranii adjuvant, monoclonal antibody, cancers

\section{Introduction}

Human chorionic gonadotropin (hCG) is not made normally by a woman and its appearance in urine or blood is taken as an indication of the on-set of pregnancy. With these established criteria, we made vaccine-inducing antibodies against hCG, which should be safe in a non-pregnant female devoid of hCG. As hCG plays an important role in the establishment of pregnancy, vaccine-inducing antibodies neutralizing hCG should prevent pregnancy. This was proven to be true by our phase II clinical trials conducted on the initial vaccine developed by us [1]. To enhance immunogenicity, $\beta$-hCG was linked non-covalently to $\alpha$-subunit of ovine luteinizing hormone (LH). This heterospecies dimer (HSD) linked to tetanus toxoid (TT) was more

(C) The Author(s) 2021. This is an Open Access article licensed under a Creative Commons Attribution 4.0 International License (https://creativecommons.org/licenses/by/4.0/), which permits unrestricted use, sharing, adaptation, distribution and reproduction in any medium or format, for any purpose, even commercially, as long as you give appropriate credit to the original author(s) and the source, provide a link to the Creative Commons license, and indicate if changes were made. 
immunogenic and induced higher antibody titers than hCG $\beta$-TT [2]. It was then taken through phase I safety followed by phase II efficacy trials with the approval of ethics and drugs regulatory authorities. All women immunized generated antibodies. On the decline of titers, they were given booster injections to maintain antibody titers above $50 \mathrm{ng} / \mathrm{mL}$. They all remained protected from becoming pregnant. Only 1 pregnancy occured in 1224 cycles [1]. Antibody response in 4 women of proven fertility who were sexually active, is shown in Figure 1.
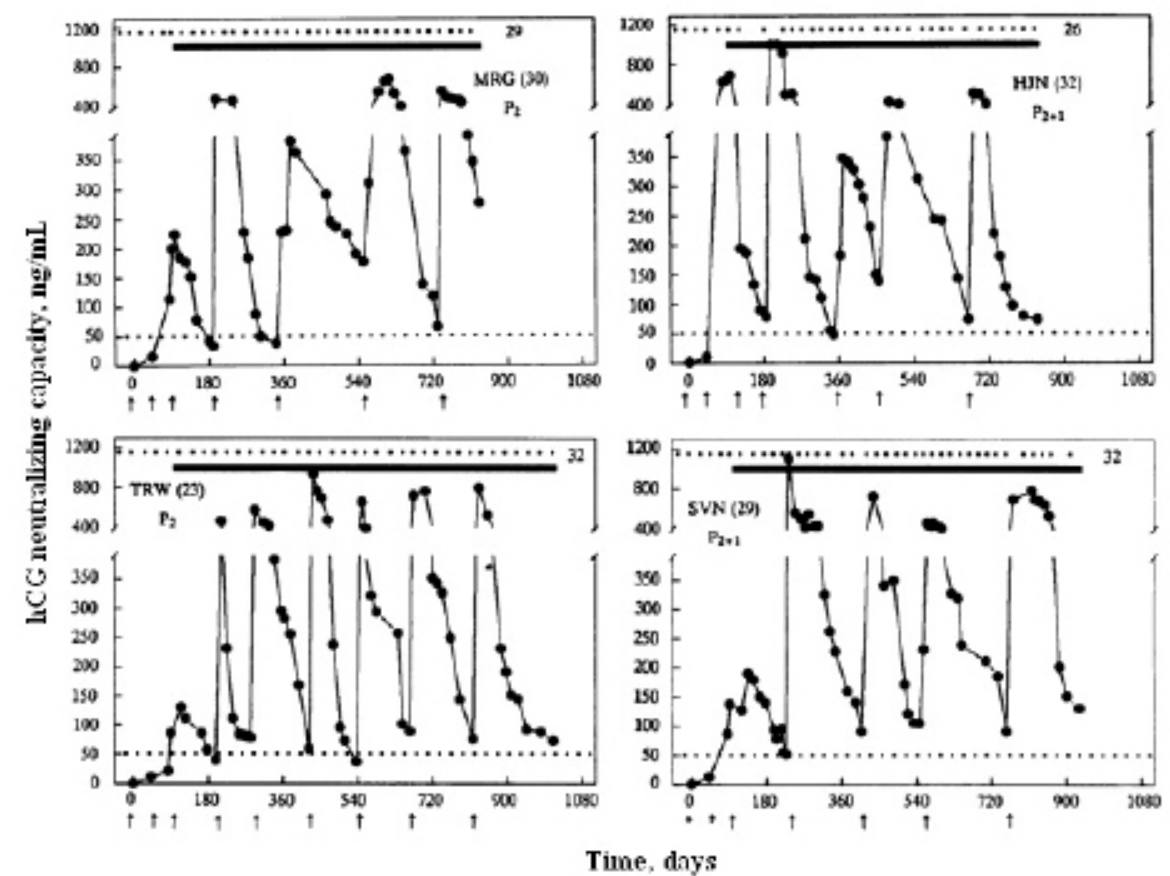

Figure 1. Anti-hCG response to the HSD vaccine in 4 sexually active women of proven fertility. MRG 30-yr-old and TRW 23-yr-old had 2 children each; MJN 32-yr-old and SVN 29-yr-old had 2 children each and 1 elective termination of pregnancy. All of them remained protected from becoming pregnant over 26-32 cycles. Dots at the top edge represent the menstrual events that remained regular, solid lines denote the period over which they were exposed to pregnancy. Arrows indicate the day on which the vaccine was given. Booster injections were given to keep antibody titers above $50 \mathrm{ng} / \mathrm{mL}$

Note. Reprinted from "A vaccine that prevents pregnancy in women” by Talwar GP, Singh O, Pal R, Chatterjee N, Sahai P, Dhall K, et al. Proc Natl Acad Sci U S A. 1994;91:8532-6 (https://doi.org/10.1073/pnas.91.18.8532). (C 1994 National Academy of Sciences.

All women continued to ovulate as indicated by progesterone in the luteal phase. Menstrual regularity was maintained. Antibodies generated by the vaccine did not intervene with normal reproductive functions. They remained sexually active.

The block of fertility was reversible. With the decline of antibodies titers, women desiring further a child, conceived at antibody titers below $10 \mathrm{ng} / \mathrm{mL}$ and gave birth to normal children fully comparable to others in the family born before they joined the trials [3].

I retired as director of the National Institute of Immunology (NII), New Delhi, India, and my successor asked me to leave the vaccine with NII. However, nothing was done. In 2006, I received a grant under Indo-US Bilateral Program to revive the vaccine. We now thought of making a genetically engineered recombinant vaccine so that it can be made at low cost with consistent characteristics, and made accessible to all, wherever they are, including France.

In the new vaccine, the $\beta$-subunit of hCG was linked to B subunit of heat-labile enterotoxin (LTB) of Escherichia coli as a carrier (Figure 2). The carrier chosen in this design of the vaccine does not evoke carrier-induced-immuno-suppression which TT as carrier did on continuous repeated use for long periods [4]. The B subunit of enterotoxin does not have these disadvantages. LTB has also adjuvant properties and evokes a mucosal response.

Keeping all these properties in mind, LTB was used to replace the previous carriers TT and diphtheria toxoid (DT) [5]. 


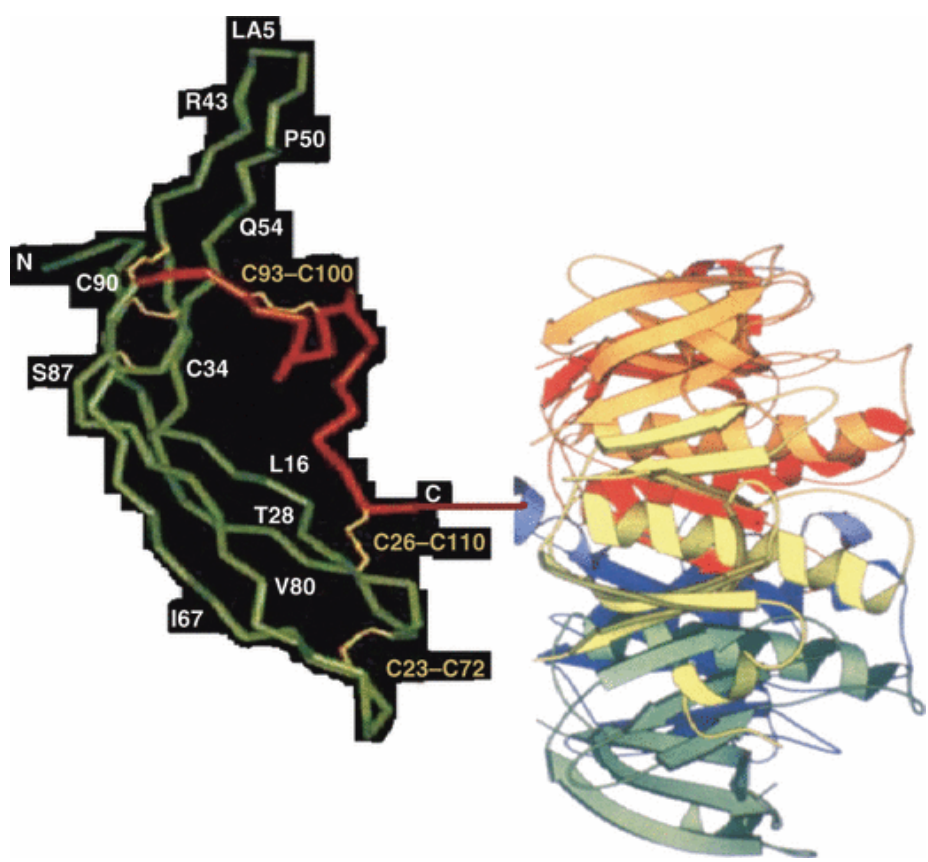

Figure 2. Recombinant anti-hCG vaccine $h C G \beta-L T B$. The carrier LTB is linked at the C-terminal amino acid glutamine of $h C G \beta$. Reproduced from [6]

Note. Reprinted from "Possibility and potential of a vaccine against human chorionic gonadotropin for family planning" by Purswani S, Lohiya NK, Talwar GP. Curr Sci. 2010;99:169-76 (https://www.currentscience.ac.in/Volumes/99/02/0169.pdf). (C 2010 Current Science Association.

\section{Inclusion of Mycobacterium indicus pranii as a potent invigorator of immune response}

The hCG $\beta$-LTB vaccine adsorbed on alhydrogel was used along with heat-killed Mycobacterium indicus pranii (MIP formerly known as $M w$ ), a vaccine which we had developed originally against leprosy. MIP is a potent potentiator of humoral and cell-mediated immune responses [7]. The atomic microscopic image of MIP is shown in Figure 3. Figure 4 shows bioneutralization capacity of hCG by antibodies generated by hCG $\beta$-LTB vaccine given with and without MIP.

Besides enhancing substantially antibody titers generated by the genetically engineered hCG $\beta$-LTB vaccine, MIP brings in additional advantages to the body. It is effective against tuberculosis and several cancers $[8,9]$.

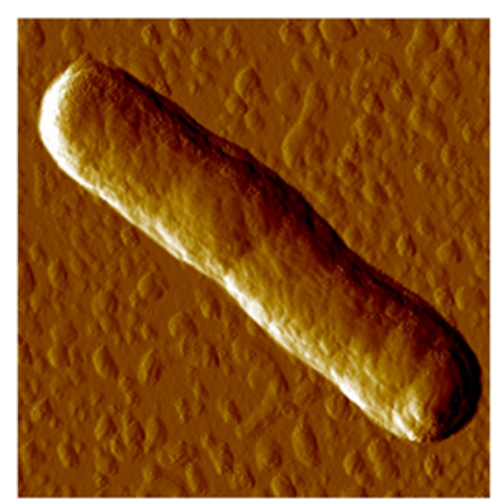

$3 \mu \mathrm{m}^{2}$ scan area

Figure 3. Atomic force microscopic image of MIP

Note. Adapted from "An immunotherapeutic vaccine originally developed against leprosy is effective not only against leprosy but also against tuberculosis, ano-genital warts and some cancers-a potent invigorator of immune response" by Talwar GP, Sonar K, Gupta JC, Puruswani S, Bhaskar S, Panda AK, et al. Int J Infect Dis. 2020;1:1-9 (https://unisciencepub.com/storage/2020/07/AnImmunotherapeutic-Vaccine-Originally-Developed.pdf). @ 2020 GP Talwar. 

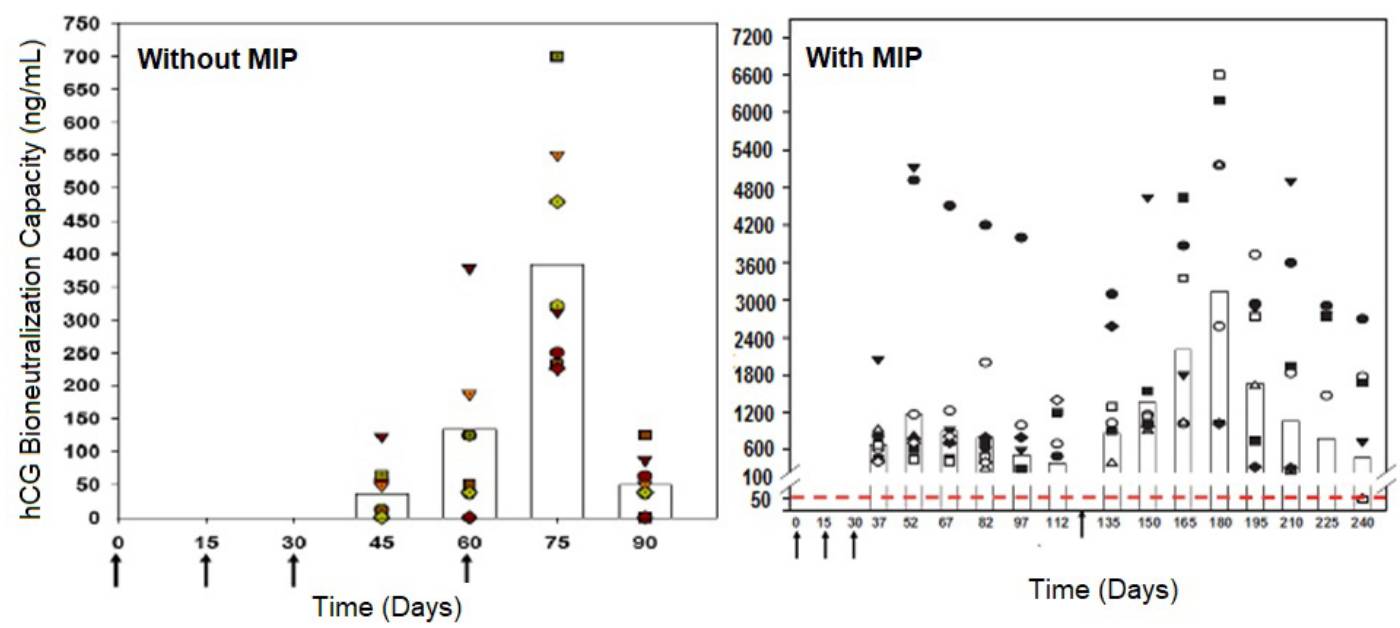

Figure 4. Enhancement of antibody response to the hCG $\beta$-LTB vaccine in Balb/c mice by MIP. Mice were immunized intra-muscularly with $2 \mu \mathrm{g}$ of the vaccine adsorbed on alum with or without MIP. Primary immunization consisted of 3 injections given at fortnightly intervals followed by a booster on day 60 or 120 . The symbols represent the titers in a given mouse. Bars give the geometrical means

Note. Reprinted from "Making of vaccines against human chorionic gonadotrophin for control of fertility of women without impairment of ovulation and menstrual regularity" by Talwar GP, Gupta JC, Nand KN, Thapa R, Mehta M. Reproductiv Immunol Open Acc. 2016;1:4 (https://doi.org/10.21767/2476-1974.100004). CC BY.

Very recently 2 clinical trials with MIP on coronavirus disease 2019 (COVID-19) infected patients have been published. In one conducted at Fortis Hospital in Mumbai, 117 patients suffering from COVID-19, were given treatment with $M I P(M w), 0.3 \mathrm{~mL}$ intradermal injections every day for 3 days, It led to rapid recovery of 116 patients. No systemic side-effects were observed of using $M w, M I P$ [10]. Another randomized trial with MIP $(M w)$ has been carried out in critically ill patients infected with COVID-19 in Delhi. The trial was on 42 subjects (22 patients treated with $M I P, 20$ with placebo). On days 14 and 21, subjects on the $M w$ (previous code of MIP) arm had a better clinical status than placebo [11]. No adverse events related to MIP use were observed.

\section{Resumption of clinical trial}

We obtained the approval of the Review Committee of Genetic Manipulations (RCGM) for our recombinant vaccine after extensive toxicology studies. With the permission of the Drugs Controller General of India (DCGI) and ethics committees, a combined phase I/II trial has started at the All India Institute of Medical Sciences, New Delhi, and Sir Gangaram Hospital, New Delhi, India. Before the unforeseen COVID epidemic, 9 women received the primary injections consisting of 2 injections at fortnight intervals of the DNA version of the recombinant vaccine followed by 2 injections of the protein version of the recombinant vaccine. As the recombinant vaccine is first made in DNA form, followed by its expression as protein, we have tested in mice, the immunogenicity of the combined use of the DNA form of the vaccine for priming, followed by the protein version of the vaccine. This mode of immunization generates a higher antibody response in mice (Figure 5) [12], hence the adoption of this regime for the clinical trial.

An unexpected observation was the formation of nodules at the site of immunization in 3 women. Experiments were carried out in mice, where again nodules were seen after 2 injections of the DNA version followed by 2 injections of the protein version of the vaccine, all given intradermally with MIP as adjuvant (unpublished observations). We hypothesized that repeated use of the adjuvant in all 4 injections may have caused the formation of nodules. Employing MIP only in the first DNA version of the vaccine followed by the remaining one injection of DNA and two of the protein versions of the recombinant vaccine without MIP was seen to avoid the formation of nodules in mice. This mode of immunization will be followed in the clinical trial.

The recombinant vaccine has been passed on to M/s Bharat Biotech, who are making the recombinant vaccine under GMP conditions and supplying it free of charge for the clinical trial. The clinical trial has been interrupted by the COVID-19 epidemic. It will be resumed on the removal of the restrictions. 

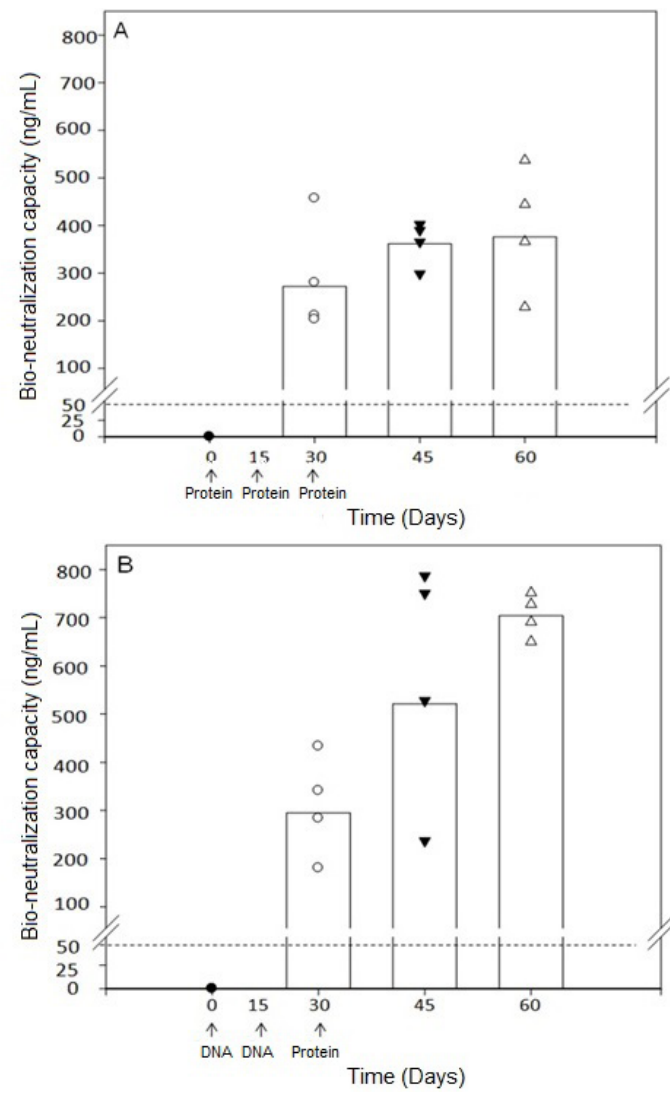

Figure 5. Bioneutralization capacity of anti-hCG antibodies. (A) Immunization with protein form of the vaccine for the three primary injections; (B) immunization with DNA form of the vaccine for the first two injections followed by protein form of the vaccine. A dotted line of $50 \mathrm{ng} / \mathrm{mL}$ is the protective threshold of antibodies for preventing pregnancy in humans

Note. Reprinted from "Priming with DNA enhances considerably the immunogenicity of hCG $\beta$-LTB vaccine" by Nand KN, Gupta JC, Panda AK, Jain SK, Talwar GP. Am J Reprod Immunol. 2015;74:302-8 (https://doi.org/10.1111/aji.12388). () 2014 Wiley Blackwell.

\section{Immunotherapy of cancers ectopically secreting hCG}

A number of papers have appeared reporting the ectopic synthesis of hCG by a variety of cancers at the advanced stage: lung cancer [13], bladder carcinoma [14], colorectal carcinoma [15], pancreatic carcinoma [16], breast cancer [17], cervical carcinoma [18], oral cancers [19], vulva/vaginal cancers [20], prostate cancer [21] and gastric carcinomas [22]. At this stage, the tumors are highly metastasizing and aggressive. We confirmed in mice that antibodies generated against hCG bind selectively to the tumor secreting hCG and not elsewhere in the body (Figure 6) [23]. What is amazing and highly interesting is that antibodies against hCG exercise impressive cytotoxicity on tumor cells expressing ectopically hCG (Figure 7).
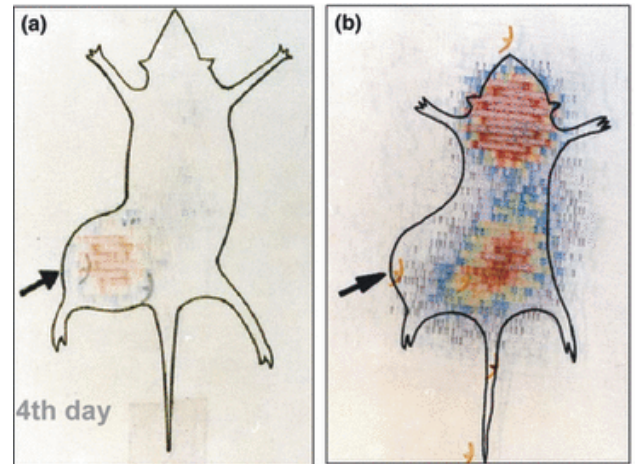

Figure 6. Imaging and selective delivery of radiations to tumors expressing hCG. (a) Whole-body scan of a JEG-3 tumor-bearing nude mouse on 4th day after injection of ${ }^{131}$ I anti-hCG monoclonal antibody; (b) whole-body scan of a JEG-3 tumor-bearing nude mouse injected with ${ }^{131}$ I irrelevant monoclonal antibody on day 4

Note. Adapted from "Immunological approaches against human chorionic gonadotropin for control of fertility and therapy of advanced-stage cancers expressing hCG/subunits" by Talwar GP, Gupta JC, Shankar NV. Am J Reprod Immunol. 2011;66:26-39 (https://doi.org/10.1111/j.1600-0897.2011.01002.x). @ 2011 Wiley Blackwell. 


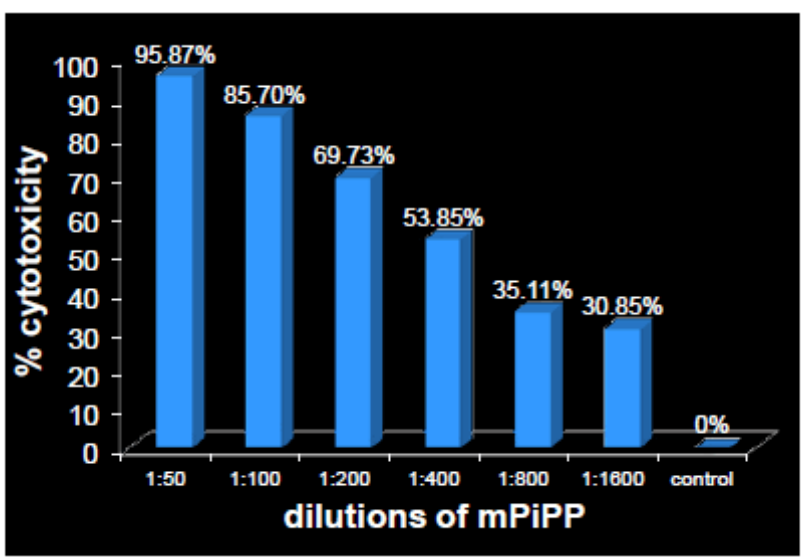

Figure 7. Dose-dependent cytotoxicity exercised by the monoclonal anti-hCG-antibody PiPP on lung cancer cells (A549)

Note. Reprinted from "Immuno-Interception of Human Chorionic Gonadotropin has Two Applications of Extraordinary Utility" by Talwar GP, Gupta JC. Perceptions Reprod Med. 2019;3:PRM.000565 (http://dx.doi.org/10.31031/prm.2019.03.000565). @ 2018 Talwar GP.

Thus an additional unforeseen use of anti-hCG vaccine along with humanized antibodies will be in the treatment of such cancers.

\section{Conclusions}

A recombinant vaccine against hCG has been made and passed onto the industry. It is highly immunogenic. Its safety has been established and approval has been received from the DCGI and ethics committees for confirming its ability to prevent pregnancy by another trial. The trial which started around 24 months back is suspended due to the COVID-19 pandemic. An additional, but highly useful application of this vaccine is expected in advanced stage cancers expressing ectopically hCG.

\section{Abbreviations}

COVID-19: coronavirus disease 2019

hCG: human chorionic gonadotropin

LTB: heat-labile enterotoxin

MIP: Mycobacterium indicus pranii

TT: tetanus toxoid

\section{Declarations}

\section{Author contributions}

GPT developed the concept and coordinated the research work cited in the review. JCG, SP, KNN, and PP contributed to the development of the recombinant hCG vaccine and its evaluation. HKV undertook studies on immunotherapy of cancers cells. KME contributed to making available the GMP grade vaccine for the clinical trial.

\section{Conflicts of interest}

The authors declare no conflict of interest.

\section{Ethical approval}

Not applicable.

\section{Consent to participate}

Not applicable. 


\section{Consent to publication}

Not applicable.

\section{Availability of data and materials}

Not applicable.

\section{Funding}

Part of the work reviewed in this article received grants from the Indian Council of Medical Research and the Department of Biotechnology, Ministry of Science and Technology, Govt of India. The funders had no role in study design, data collection and analysis, decision to publish, or preparation of the manuscript.

\section{Copyright}

(C) The Author(s) 2021.

\section{References}

1. Talwar GP, Singh O, Pal R, Chatterjee N, Sahai P, Dhall K, et al. A vaccine that prevents pregnancy in women. Proc Natl Acad Sci U S A. 1994;91:8532-6.

2. Talwar GP, Singh O, Rao LV. An improved immunogen for anti-human chorionic gonadotropin vaccine eliciting antibodies reactive with a conformation native to the hormone without cross-reaction with human follicle stimulating hormone and human thyroid stimulating hormone. J Reprod Immunol. 1988;14:203-12.

3. Singh M, Das SK, Suri S, Singh O, Talwar GP. Regain of fertility and normality of progeny born during below protective threshold antibody titers in women immunized with the HSD-hCG vaccine. Am J Reprod Immunol. 1998;39:395-8.

4. Kaliyaperumal A, Chauhan VS, Talwar GP, Raghupathy R. Carrier-induced epitope-specific regulation and its bypass in a protein-protein conjugate. Eur J Immunol. 1995;25:3375-80.

5. Purswani S, Talwar GP. Development of a highly immunogenic recombinant candidate vaccine against human chorionic gonadotropin. Vaccine. 2011;29:2341-8.

6. Purswani S, Lohiya NK, Talwar GP. Possibility and potential of a vaccine against human chorionic gonadotropin for family planning. Curr Sci. 2010;99:169-76.

7. Purswani S, Talwar GP, Vohra R, Pal R, Panda AK, Lohiya NK, et al. Mycobacterium indicus pranii is a potent immunomodulator for a recombinant vaccine against human chorionic gonadotropin. J Reprod Immunol. 2011;91:24-30.

8. Gupta A, Saqib M, Singh B, Pal L, Nishikanta A, Bhaskar S. Mycobacterium indicus pranii induced memory T-Cells in lung airways are sentinels for improved protection against M.tb infection. Front Immunol. 2019;10:2359.

9. Subramaniam M, In LL, Kumar A, Ahmed N, Nagoor NH. Cytotoxic and apoptotic effects of heat killed Mycobacterium indicus pranii (MIP) on various human cancer cell lines. Sci Rep. 2016;6:19833.

10. Ingale A, Ingale F, Kunwar B, Ahmed S, Salvi K, Chavan V, et al. Role of Mycobacterium $w$ for the treatment of COVID-19: an observational study. J Assoc Physicians India. 2021;69:19-22.

11. Sehgal IS, Guleria R, Singh S, Siddiqui MS, Agarwal R. A randomised trial of Mycobacterium $w$ in critically ill patients with COVID-19: ARMY-1. ERJ Open Res. 2021;7:00059-2021.

12. Nand KN, Gupta JC, Panda AK, Jain SK, Talwar GP. Priming with DNA enhances considerably the immunogenicity of hCG $\beta$-LTB vaccine. Am J Reprod Immunol. 2015;74:302-8.

13. Dirnhofer S, Freund M, Rogatsch H, Krabichler S, Berger P. Selective expression of trophoblastic hormones by lung carcinoma: neurendocrine tumors exclusively produce human chorionic gonadotropin alpha-subunit (hCGalpha). Hum Pathol. 2000;31:966-72. 
14. Dirnhofer S, Koessler P, Ensinger C, Feichtinger H, Madersbacher S, Berger P. Production of trophoblastic hormones by transitional cell carcinoma of the bladder: association to tumor stage and grade. Hum Pathol. 1998;29:377-82.

15. Louhimo J, Carpelan-Holmström M, Alfthan H, Stenman UH, Järvinen HJ, Haglund C. Serum HCG beta, CA 72-4 and CEA are independent prognostic factors in colorectal cancer. Int J Cancer. 2002;101:545-8.

16. Syrigos KN, Fyssas I, Konstandoulakis MM, Harrington KJ, Papadopoulos S, Milingos N, et al. Beta human chorionic gonadotropin concentrations in serum of patients with pancreatic adenocarcinoma. Gut. 1998;42:88-91.

17. Agnantis NJ, Patra F, Khaldi L, Filis S. Immunohistochemical expression of subunit beta HCG in breast cancer. Eur J Gynaecol Oncol. 1992;13:461-6.

18. Crawford RA, Iles RK, Carter PG, Caldwell CJ, Shepherd JH, Chard T. The prognostic significance of beta human chorionic gonadotrophin and its metabolites in women with cervical carcinoma. J Clin Pathol. 1998;51:685-8.

19. Hedström J, Grenman R, Ramsay H, Finne P, Lundin J, Haglund C, et al. Concentration of free hCGbeta subunit in serum as a prognostic marker for squamous-cell carcinoma of the oral cavity and oropharynx. Int J Cancer. 1999;84:525-8.

20. de Bruijn HW, ten Hoor KA, Krans M, van der Zee AG. Rising serum values of beta-subunit human chorionic gonadotrophin (hCG) in patients with progressive vulvar carcinomas. Br J Cancer. 1997; 75:1217-8.

21. Sheaff MT, Martin JE, Badenoch DF, Baithun SI. beta hCG as a prognostic marker in adenocarcinoma of the prostate. J Clin Pathol. 1996;49:329-32.

22. Zhang W, Yang H, Han S. The effect of ectopic HCG on microvessel density in gastric carcinoma. Zhonghua Zhong Liu Za Zhi. 1998;20:351-3. Chinese.

23. Talwar GP, Gupta JC, Shankar NV. Immunological approaches against human chorionic gonadotropin for control of fertility and therapy of advanced-stage cancers expressing hCG/subunits. Am J Reprod Immunol. 2011;66:26-39. 